University of Arkansas, Fayetteville

ScholarWorks@UARK

3-11-2019

\title{
The Effects of Regulations on Private School Choice Program Participation: Experimental Evidence from California and New York
}

Corey DeAngelis

Cato Institute

Lindsey Burke

The Heritage Foundation

Patrick J. Wolf

University of Arkansas, Fayetteville, pwolf@uark.edu

Follow this and additional works at: https://scholarworks.uark.edu/edrepub

Part of the Educational Assessment, Evaluation, and Research Commons, and the Elementary and Middle and Secondary Education Administration Commons

\section{Citation}

DeAngelis, C., Burke, L., \& Wolf, P. J. (2019). The Effects of Regulations on Private School Choice Program Participation: Experimental Evidence from California and New York. Education Reform Faculty and Graduate Students Publications. Retrieved from https://scholarworks.uark.edu/edrepub/74

This Article is brought to you for free and open access by the Education Reform at ScholarWorks@UARK. It has been accepted for inclusion in Education Reform Faculty and Graduate Students Publications by an authorized administrator of ScholarWorks@UARK. For more information, please contact scholar@uark.edu. 


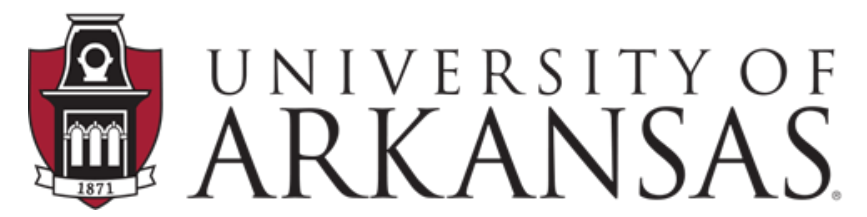

College of Education \& Health Professions Education Reform

\title{
WORKING PAPER SERIES
}

\section{The Effects of Regulations on Private School Choice Program Participation: Experimental Evidence from California and New York}

\author{
Corey A. DeAngelis, Ph.D. \\ Lindsey M. Burke, Ph.D. \\ Patrick J. Wolf, Ph.D.
}

March 12, 2019

EDRE Working Paper 2019-07

The University of Arkansas, Department of Education Reform (EDRE) working paper series is intended to widely disseminate and make easily accessible the results of EDRE faculty and students' latest findings. The Working Papers in this series have not undergone peer review or been edited by the University of Arkansas. The working papers are widely available, to encourage discussion and input from the research community before publication in a formal, peer reviewed journal. Unless otherwise indicated, working papers can be cited without permission of the author so long as the source is clearly referred to as an EDRE working paper. 
The Effects of Regulations on Private School Choice Program Participation: Experimental Evidence from California and New York

\author{
Corey A. DeAngelis, Ph.D.* \\ Cato Institute \\ 1000 Massachusetts Ave NW, \\ Washington, DC 20001 \\ CDeAngelis@cato.org \\ ORCID: 0000-0003-4431-9489 \\ Lindsey M. Burke, Ph.D. \\ Heritage Foundation \\ 214 Massachusetts Ae NE, \\ Washington, DC 20002 \\ lindsey.burke@ heritage.org \\ Patrick J. Wolf, Ph.D. \\ University of Arkansas \\ 1 University of Arkansas, \\ Fayetteville, AR 72701 \\ pwolf@uark.edu
}

March 12, 2019

*Corresponding author is Corey A. DeAngelis, Corey.DeAngelis@ gmail.com, (210) 818-6713. Declarations of interest: none. Funding: none. 


\begin{abstract}
Although private school voucher programs provide subsidies to students for tuition and other education-related costs, private school leaders weigh program participation against any associated regulatory costs. The higher the regulatory costs of participation, the less likely a private school is to participate in a school voucher program. Since we do not know with certainty which regulations will be viewed by school leaders as more or less costly, we explore whether specific regulations that are common to private school choice programs do or do not deter likely voucher program participation.
\end{abstract}

We use surveys to randomly assign different regulations to 4,825 private school leaders in the states of California and New York and ask them whether or not they would participate in a new private school choice program during the following school year. Relative to no regulations, our most conservative models find that open-enrollment mandates reduce the likelihood that private school leaders are certain to participate in a hypothetical choice program by about 19 percentage points, or 60 percent. State standardized testing requirements reduce the likelihood that private school leaders are certain to participate by 9 percentage points, or 29 percent. We find no evidence to suggest that the prohibition of copayment or nationally norm-referenced testing requirements affect the overall willingness to participate in a school choice program.

Keywords: private school; school choice; school vouchers; schooling supply; regulations JEL Classifications: I28, I20 


\section{Introduction}

As of the fall of 2018, 15 states and the District of Columbia operate 26 private school voucher programs (EdChoice, 2018). Nearly 184,000 students are currently using vouchers to offset the cost of tuition at a participating private school (EdChoice, 2018). Private school leaders decide whether to have their schools participate in these voucher programs each year, often with guidance from umbrella organizations such as school boards and archdioceses. As with other decisions, a cost-benefit analysis guides school leaders' decision to participate in a school voucher program or to decline participation. If a given private school leader expects that additional benefits of participation will exceed the additional costs, the leader will decide to participate in the program. The main benefits of participation are additional revenue from the voucher and a more expansive customer base, while the main cost is additional government regulation. Ceteris paribus, an increase in the regulatory burden associated with program participation should decrease the likelihood that private school leaders elect to participate. Although other studies find that additional voucher program regulation generally is correlated with lower rates of program participation (DeAngelis \& Burke, 2017; Sude, DeAngelis, \& Wolf, 2018), none of the existing empirical studies provides causal evidence that regulation reduces program participation, and none determines which types of regulations are the most costly to private schools.

Our previous study began to fill this considerable hole in the literature. It presented the results of the first experimental evaluation of the effects of frequently promulgated regulations on the willingness of private school leaders to participate in a hypothetical voucher program in Florida (DeAngelis, Burke, \& Wolf, 2018). We randomly assigned a hypothetical voucher program participation offer to 3,080 private school leaders in Florida in 2018. Specifically, we 
randomly assigned one of three different regulations, or no additional government regulation at all, to each of these private school leaders and asked them whether or not they would participate in the voucher program the following year. We found that the open-enrollment regulation, requiring that the school accept all interested students regardless of their level of preparation, decreased the likelihood that private school leaders in Florida were "certain to participate" by around 17 percentage points. Standardized testing requirements decreased the likelihood that private school leaders were "certain to participate" by around 12 percentage points.

We add to this literature by replicating that experiment in the states of California and New York, randomly assigning a hypothetical voucher program participation offer to 4,825 private school leaders in these two states. Our study builds upon the Florida evaluation in at least four important ways: (1) we examine two states that do not have private school choice programs; (2) we add a nationally norm-referenced testing requirement as a new regulatory treatment; (3) we include two customer review metrics as proxies for school quality; and, (4) we analyze subgroup effects by school specialization.

In the next section, we examine the theory underlying private school choice participation decisions. We then review the limited empirical literature on the question. After that, we describe our data and methods. We then spend a few sections discussing the data and methods in detail, followed by a presentation of our empirical results, including an exploration of possible heterogeneous effects. Our final section concludes with implications for further research and program design considerations. 


\section{Theory}

When deciding whether or not to participate in a private school choice program, private school leaders weigh the expected benefits of participation against the expected costs. The major benefits associated with school choice program participation include additional funding and enrollment, freeing-up resources that can be put toward other school-based scholarships for additional students, and the capacity to extend the school's mission to additional students. School leaders are likely to view additional regulations as a cost associated with program participation. In theory, raising the costs associated with entering private school choice programs should reduce the likelihood that individual schools participate in those programs. This conceptual framework suggests private school leaders will only turn down the offer to participate in a voucher program if they perceive that additional costs will exceed additional benefits of participation.

Because any school choice regulation increases the costs of program participation, we expect all four of the randomly assigned regulations to have statistically significant negative effects on private school leaders' anticipated participation in the hypothetical program. We anticipate that all four regulations- open-enrollment mandates, state standardized testing requirements, nationally norm-referenced testing requirements, and the prohibition of a parental copayment - are all costly enough to deter private schools from participating in the hypothetical private school choice programs. As autonomy is important to private school leaders and the families they serve, and since many private schools already use either norm-referenced or state standardized tests, we envisage that the regulation requiring an open enrollment admissions policy will have the largest negative effects on the likelihood that private school leaders pledge to be "certain to participate" in the new private school voucher program. Because many U.S. 
private schools face difficulties maintaining the enrollment levels necessary to ensure financial stability (Brinig \& Garnett, 2014; Murnane, Reardon, Mbekeani, \& Lamb, 2018), we think that the prohibition of copayment will have the smallest negative effects on principals' expressed willingness to participate in a hypothetical voucher program.

Policymakers and advocacy organizations, rather than private school leaders, tend to determine which regulations will be attached to private school voucher funding. Moreover, policymakers often change private school choice program regulations over time (Wolf, 2012). As shown in the next section, policymakers have made important decisions about the regulatory structure of private school choice programs without the assistance of causal evidence linking regulations to the supply of private schools that participate in choice programs.

\section{Literature Review}

The private school marketplace relies on the ability of high-quality private schools to open and expand (Chubb \& Moe, 1990; Hess, 2010; McShane, 2015; McShane, 2018). However, very little empirical research exists examining government regulations' impact on private school choice program participation. That shortcoming could be a function of the limited amount of variation in regulations across programs in the United States. Because of this weak variation, and since voucher program regulations are not randomly assigned to private schools in the United States, only one causal study exists on the topic (DeAngelis, Burke, \& Wolf, 2018). A few other empirical studies, however, offer suggestive evidence that regulations can have unintended consequences on the effectiveness of voucher programs.

The evaluation of the Louisiana Scholarship Program (LSP) is the first random assignment study in the world to detect statistically significant negative effects of a private school voucher program on student achievement (Mills, 2015; Mills \& Wolf, 2017; 
Abdulkadiroglu, Pathak, \& Walters, 2018). Abdulkadiroglu, Pathak, and Walters (2018) find evidence to suggest that lower quality private schools, as measured by student enrollment, are more likely to participate in the LSP. Other scholars report that only a third of the private schools in the state have participated in the highly regulated LSP, whereas over twice that proportion have elected to participate in less regulated school choice programs in other areas (Sude, DeAngelis, \& Wolf, 2018). Descriptive studies have also found that lower quality schools, as measured by tuition, enrollment, and customer reviews, tend to be more likely to participate in voucher programs, on average (DeAngelis \& Hoarty, 2018; Sude, DeAngelis \& Wolf, 2018). Similarly, Stuit and Doan (2013) find that higher levels of U.S. voucher program regulatory burdens are associated with lower levels of private school participation. Private school leaders in Louisiana, Indiana, and Florida have expressed concerns over voucher program regulations (Kisida, Wolf, \& Rhinesmith, 2015). Additionally, DeAngelis and Burke (2017) report evidence to suggest that voucher program regulations homogenize the supply of private schools overall.

Although the existing studies provide some evidence that regulations reduce program participation, only one previous study is a true experiment (DeAngelis, Burke, \& Wolf, 2018). We fill this hole in the literature by conducting the second random-assignment study on the effects of regulation on the expressed intentions of private school leaders to participate or not in a school choice program. Our study builds upon the first evaluation in at least four important ways: (1) we examine two states, California and New York, that do not have any private school choice programs; (2) we add a nationally norm-referenced testing requirement as a new regulatory treatment; (3) we include two customer review metrics as proxies for school quality; and, (4) we analyze subgroup effects by school specialization. 


\section{Data and Research Design}

We obtained a complete list of 4,825 individual private schools in September of 2018. We used the California Private Schools Directory located at the California Department of Education's website to find a complete list of 3,076 private schools in the Eureka State. ${ }^{1}$ We used the Directory of Public and Nonpublic Schools and Administrators in New York State, located on the New York State Department of Education's website, to find a complete list of 1,749 private schools in the Empire State. ${ }^{2}$ These data sources provided us with contact information for the private school leaders and school background characteristics such as address, city, grades served, school level, religious affiliation, and student enrollment.

We randomly assigned each private school to one of five groups, the control group or one of four different experimental groups, using the complete list of 4,825 private schools. Each of the five groups received a survey containing 10 identical questions about basic school and leader background characteristics that were used as control variables. The $11^{\text {th }}$ and final question in each of the five surveys differed experimentally. The control group's eleventh question asked "If your state launched a new school choice program next academic year, with a value of $\$ 6,000$ per student, per year, how likely is it that your school would participate in the program? Note: This program would not require any changes in school operations or additional government regulations." The first treatment group, capturing the effect of open-enrollment policy, had a note on question 11 indicating "The only requirement would be that your school would have to accept all students who applied (and you would be required to use a random lottery for admissions in the case of oversubscription)." The second treatment group, capturing the effect of state standardized testing requirements on program participation, had a note on question 11 indicating

\footnotetext{
${ }^{1}$ Private Schools. California Department of Education. Retrieved from https://www.cde.ca.gov/ds/si/ps/.

2 Directory of Public and Nonpublic Schools and Administrators in New York State. New York State Department of Education. Retrieved from http://www.p12.nysed.gov/irs/schoolDirectory/.
} 
"The only requirement would be that every student would have to take the state standardized tests each year." The third treatment group, capturing the effect of nationally norm-referenced standardized testing requirements on program participation, had a note on question 11 indicating "The only requirement would be that every student would have to take nationally normreferenced standardized tests each year." The final treatment group, capturing the effect of a parent copayment prohibition, had a note on question 11 indicating "The only requirement would be that your school would have to accept the voucher amount $(\$ 6,000)$ as full payment for voucher students." The full survey instrument can be found in the Appendix.

Out of the complete list of 4,825 schools, we randomly assigned 4,732 of the private schools to one of the five experimental groups. We dropped 93 (1.93 percent) of the original observations because they were missing email addresses. We assigned 964 schools to the control group (no regulations), 926 to the state standardized testing treatment, 966 to the openenrollment treatment, 934 to the copay prohibition treatment, and 942 to the nationally normreferenced standardized testing treatment (Table 1). Because of duplicates and bounced emails, we actually sent out 898 emails to the control group, 858 emails to the state testing group, 865 emails to the open-enrollment group, 843 emails to the copay prohibition group, and 862 emails to the nationally norm-referenced testing group for a total potential sample size of 4,322 private schools. We sent initial emails on September 12, 2018 at 1:37pm ET, first reminders on September 18, 2018 at 2:37pm ET, second reminders on September 24, 2018 at 1:33pm ET, third reminders on September 28, 2018 at 1:32pm ET, fourth reminders on October 4, 2018 at 1:38pm ET, fifth reminders on October 10, 2018 at 12:37pm ET, and final reminders on October 18, 2018 at 1:59pm ET. 
We received 356 total survey responses by October 26, 2018 for a total response rate of 8.24 percent. As shown in Table 1 below, none of the four treatment groups' response rates were statistically different from the control group's response rate.

Table 1: Response Rates by Experimental Group

\begin{tabular}{|l|l|l|l|l|l|}
\hline Distribution & Control & $\begin{array}{l}\text { Open- } \\
\text { Enrollment }\end{array}$ & $\begin{array}{l}\text { State } \\
\text { Testing }\end{array}$ & $\begin{array}{l}\text { National } \\
\text { Testing }\end{array}$ & $\begin{array}{l}\text { Copay } \\
\text { Prohibition }\end{array}$ \\
\hline Assigned & 964 & 966 & 926 & 942 & 934 \\
\hline Emailed & 898 & 865 & 854 & 862 & 843 \\
\hline Surveys Started & 173 & 142 & 151 & 154 & 149 \\
\hline Responded & 73 & 68 & 75 & 68 & 72 \\
\hline Start Rate & $19.27 \%$ & $16.42 \%$ & $17.68 \%$ & $17.87 \%$ & $17.67 \%$ \\
\hline Response Rate & $8.13 \%$ & $7.86 \%$ & $8.78 \%$ & $7.89 \%$ & $8.54 \%$ \\
\hline Completion Rate & $42.20 \%$ & $47.89 \%$ & $49.67 \%$ & $44.16 \%$ & $48.32 \%$ \\
\hline
\end{tabular}

Notes: $+\mathrm{p}<0.10,{ }^{*} \mathrm{p}<0.05, * * \mathrm{p}<0.01, * * * \mathrm{p}<0.001$. Statistical significance was calculated using a chi-squared test for each treatment column. "Emailed" excludes observations with duplicate emails and observations with emails that bounced. "Start Rate" equals "Surveys Started" divided by "Emailed." "Response Rate" equals "Responded" divided by "Emailed." "Completion Rate" equals "Responded" divided by "Surveys Started."

\section{Internal Validity}

One way to test for potential bias arising from low response rates is to check for equivalence on observable characteristics. As shown in Table 2 below, individual t-tests do not detect any differences across any of the 33 observable characteristics between the control group and the two standardized testing treatment groups at the 95 percent level of confidence. One statistically significant difference emerges for the copay prohibition treatment group. This finding suggests that the respondents to the copay prohibition treatment group are more likely to classify themselves as "other leaders" than respondents in the control group. This one difference, however, could very well be a type I error or "false discovery" given the large number of statistical comparisons being made.

We detect five statistically significant differences between the control group and the open-enrollment treatment group, suggesting that respondents in the open-enrollment group were more likely to report that they were "other leaders," that they were "alternative" school leaders, 
and that they were leaders of "K-12 schools" than were respondents in the control group. The respondents in the open-enrollment group were less likely to report that they were leaders of "regular" schools and "K-8" schools. Table 2 demonstrates moderate evidence that randomization worked and, therefore, that our estimates are reasonably unbiased. That said, we also provide results from models using all control variables.

In theory, differences on observables detected for the open-enrollment group could introduce bias into the analysis if the leaders also opted into responding to that particular survey based on unobservable characteristics. However, the most plausible reason for selection bias into the open-enrollment survey has to do with the potential for strong social desirability bias (Phillips \& Clancy, 1972). If the school leaders perceived that the survey results would be published online (although we assured them that their individual responses would be kept completely confidential), they would have an incentive to avoid responding to the openenrollment survey if their school did not want to take all students at random. Even if the leaders had good intentions, a response indicating that they did not want to use random lottery admissions could be bad publicity because the categorical response does not allow for a nuanced discussion of the actual policy. This social desirability bias would not be as likely to deter leaders who are comfortable with an open-enrollment regulation from responding to the survey. This type of bias would also not be as likely to deter leaders in the control group from opting out of the survey, as school leaders presumably would perceive little, if any, negative connotation associated with not wanting to participate in a school choice program without any additional regulations. 
Table 2: Equivalence on Observables

\begin{tabular}{llllll}
\hline Observable & Control & $\begin{array}{l}\text { Open- } \\
\text { Enrollment }\end{array}$ & $\begin{array}{l}\text { State } \\
\text { Testing }\end{array}$ & $\begin{array}{l}\text { National } \\
\text { Testing }\end{array}$ & $\begin{array}{l}\text { Copay } \\
\text { Prohibited }\end{array}$ \\
\hline California & 0.71 & 0.65 & 0.68 & 0.79 & 0.72 \\
New York & 0.29 & 0.35 & 0.32 & 0.21 & 0.28 \\
Asian & 0.08 & 0.04 & 0.07 & 0.06 & 0.06 \\
Hispanic & 0.04 & 0.07 & 0.08 & 0.04 & 0.03 \\
Black & 0.04 & 0.03 & 0.08 & 0.07 & 0.03 \\
White & 0.77 & 0.75 & 0.79 & 0.72 & 0.83 \\
Pacific Islander & 0.01 & 0.00 & 0.00 & 0.00 & 0.01 \\
Other Race & 0.01 & 0.03 & 0.03 & 0.06 & 0.01 \\
Female & 0.59 & 0.60 & 0.64 & 0.72 & 0.71 \\
Male & 0.41 & 0.40 & 0.36 & 0.28 & 0.29 \\
Principal & 0.66 & 0.57 & 0.57 & 0.59 & 0.61 \\
Administrator & 0.12 & 0.18 & 0.17 & 0.15 & 0.17 \\
Director & 0.21 & 0.16 & 0.20 & 0.19 & 0.13 \\
Other Leader & 0.01 & $0.09 *$ & 0.05 & $0.07+$ & $0.10 *$ \\
Regular School & 0.71 & $0.53 *$ & 0.64 & 0.65 & 0.76 \\
Montessori School & 0.08 & 0.04 & 0.07 & 0.06 & 0.06 \\
Early Childhood School & 0.01 & 0.03 & 0.03 & 0.06 & 0.01 \\
Alternative School & 0.11 & $0.24 *$ & 0.09 & 0.18 & 0.11 \\
SPED School & 0.04 & 0.07 & 0.08 & 0.04 & 0.03 \\
Specialized School & 0.04 & 0.09 & 0.09 & 0.01 & 0.03 \\
Elementary School & 0.14 & 0.16 & 0.20 & 0.13 & 0.13 \\
K-8 School & 0.38 & $0.18 * *$ & 0.27 & 0.26 & 0.40 \\
K-12 School & 0.11 & $0.28 *$ & 0.11 & 0.16 & 0.11 \\
9-12 School & 0.05 & 0.06 & 0.03 & 0.06 & 0.08 \\
Junior Senior School & 0.04 & 0.04 & 0.04 & 0.03 & 0.07 \\
Senior High School & 0.04 & 0.04 & 0.04 & 0.03 & 0.04 \\
Latitude of Response & 37.26 & 37.26 & 37.54 & 37.07 & 37.19 \\
Longitude of Response & -105.08 & -104.33 & -104.69 & -110.62 & -106.60 \\
Enrollment & 270 & 237.46 & 234 & $187.84+$ & 247.60 \\
Google Score & 4.46 & 4.26 & 4.31 & 4.38 & 4.40 \\
GreatSchools Score & 4.09 & 4.15 & 4.23 & 4.27 & 4.20 \\
Tuition (Dollars) & 11,149 & $15,168+$ & 11,786 & 12,464 & 12,609 \\
Religious (CA Only) & 0.73 & $0.55+$ & $0.57+$ & 0.67 & 0.77 \\
\hline N & 73 & 68 & 75 & 68 & 72 \\
\hline
\end{tabular}

Notes: $+\mathrm{p}<0.10,{ }^{*} \mathrm{p}<0.05, * * \mathrm{p}<0.01, * * * \mathrm{p}<0.001$. Statistical significance was calculated using a t-test for each treatment column.

As explained in DeAngelis, Burke, \& Wolf (2018), the bias introduced into the results for the open-enrollment treatment condition should be upwards in direction, meaning the obtained rate of "yes" responses to participating is higher than the true rate would be in the absence of non-response. This upward bias in the "yes" responses would make it more difficult to detect the 
theorized negative effect of regulation on program participation. This means that any detected negative effects for the open-enrollment regulatory treatment could be lower bounds of the true estimates. The best explanation for this occurrence is the potential social desirability bias introduced by the randomly assigned note regarding open-enrollment.

\section{External Validity}

Although we do not find evidence to suggest a problem of internal validity, a low overall response rate of 8.42 percent may limit the external validity of our results. Our sample of respondents might not be representative of the entire population of private school leaders in California and New York, so the results might not be generalizable to all private schools in these states. However, we do have access to some observable characteristics for all schools on the list of 4,825 private schools from the states' Department of Education websites. As shown in Table 3 below, out of the 10 observable characteristics that we have for respondents' schools and all schools, state, city (New York only), K-8 school, K-12 school, grades 9-12 school, elementary school, whether the school is religious (California only), and whether the school is coeducational (California only), four statistically significant differences emerge between the sample of respondents and the total private school population. At the 95 percent level of confidence, the respondents' schools in our sample are 6.5 percentage points more likely than the population average to be located in California, 8.5 percentage points more likely to be a K-8 school, 7.9 percentage points less likely to be located in Brooklyn, and 6.7 percentage points more likely to have a religious affiliation. Descriptive statistics of the full analytic sample can be found in Table 4 below. The distribution of expected program participation responses across all three states, including Florida, can be found in Table 5 below. 
Table 3: Respondents Compared to All Private Schools

\begin{tabular}{lllll}
\hline Observable & $\begin{array}{l}\text { Respondents } \\
(\#)\end{array}$ & $\begin{array}{l}\text { Respondents } \\
(\%)\end{array}$ & Population (\#) & Population (\%) \\
\hline California & 253 & $71.07 *$ & 3057 & 64.60 \\
Elementary School & 54 & 15.17 & 908 & $19.19+$ \\
K-8 School & 107 & $30.06 * * *$ & 1022 & 21.60 \\
K-12 School & 58 & 16.29 & 849 & 17.94 \\
9-12 School & 20 & 5.62 & 228 & 4.82 \\
Brooklyn (City) & 13 & 12.62 & 343 & $20.48^{*}$ \\
Bronx (City) & 7 & 6.80 & 88 & 5.25 \\
New York (City) & 13 & 12.62 & 172 & 10.27 \\
Religious (CA Only) & 167 & $66.01 *$ & 1812 & 59.27 \\
Coed (CA Only) & 244 & 96.44 & 2965 & 96.99 \\
\hline N & 356 & 356 & 4732 & 4732 \\
\hline Notes: $+\mathrm{p}<0.10,{ }^{*} \mathrm{p}<0.05, * * \mathrm{p}<0.01, * * * \mathrm{p}<0.001$. Statistical significance was calculated using a chi-squared test.
\end{tabular}

Table 4: Descriptive Statistics

\begin{tabular}{llllll}
\hline Variable & Mean & $\begin{array}{l}\text { Standard } \\
\text { Deviation }\end{array}$ & Min & Max & N \\
\hline Participation Number & 3.29 & 1.36 & 1 & 5 & 354 \\
Certain to Participate & 0.22 & 0.42 & 0 & 1 & 354 \\
Female & 0.65 & 0.48 & 0 & 1 & 356 \\
Male & 0.35 & 0.48 & 0 & 1 & 356 \\
Black & 0.05 & 0.22 & 0 & 1 & 356 \\
Hispanic & 0.05 & 0.23 & 0 & 1 & 356 \\
White & 0.77 & 0.42 & 0 & 1 & 356 \\
Principal & 0.60 & 0.49 & 0 & 1 & 356 \\
Director & 0.18 & 0.38 & 0 & 1 & 356 \\
Regular School & 0.66 & 0.47 & 0 & 1 & 356 \\
SPED School & 0.05 & 0.23 & 0 & 1 & 356 \\
Montessori School & 0.06 & 0.24 & 0 & 1 & 356 \\
Specialized School & 0.05 & 0.23 & 0 & 1 & 356 \\
Alternative School & 0.14 & 0.35 & 0 & 1 & 356 \\
K-8 School & 0.30 & 0.46 & 0 & 1 & 356 \\
K-12 School & 0.16 & 0.37 & 0 & 1 & 356 \\
9-12 School & 0.06 & 0.23 & 0 & 1 & 356 \\
Elementary School & 0.15 & 0.36 & 0 & 1 & 356 \\
Religious School (CA) & 0.66 & 0.47 & 0 & 1 & 253 \\
Google Review Score & 4.37 & 0.70 & 1 & 5 & 315 \\
GreatSchools Review Score & 4.19 & 0.77 & 1 & 5 & 310 \\
Tuition (\$) & 12,597 & 13,547 & 0 & 99,100 & 356 \\
Enrollment & 236 & 290 & 5 & 312 & 356 \\
Enrollment Change (\%) & 21.11 & 220.03 & -79.22 & 3000 & 238 \\
California & 0.71 & 0.45 & 0 & 1 & 356 \\
New York & 0.29 & 0.45 & 0 & 1 & 356 \\
\hline
\end{tabular}

Note: "Tuition" includes 2 imputed observations generated from multiple imputation regression. 
Table 5: Distribution of Participation by State (Control Group)

\begin{tabular}{llllll}
\hline & $\begin{array}{c}\text { Certain Not } \\
\text { to Participate }\end{array}$ & $\begin{array}{c}\text { Very Little } \\
\text { Chance }\end{array}$ & Some Chance & $\begin{array}{c}\text { Very Good } \\
\text { Chance }\end{array}$ & $\begin{array}{c}\text { Certain to } \\
\text { Participate }\end{array}$ \\
\hline California & 13.46 & 1.92 & 28.85 & 21.15 & 34.62 \\
New York & 4.76 & 14.29 & 19.05 & 38.10 & 21.81 \\
Florida & 8.70 & 3.26 & 19.57 & 34.78 & 33.70
\end{tabular}

Notes: "Florida" refers to data from DeAngelis, Burke, and Wolf (2018). The percent of control group respondents selecting each participation status is shown in each column. California has 52 observations, New York has 21, and Florida has 92.

\section{Methods}

We employ an ordered probit regression approach of the form:

$$
\begin{aligned}
& \operatorname{Prob}_{\left(\text {Participation }_{\mathrm{i} 2018}\right)}=\beta_{0}+\beta_{1} \text { Open_Enroll }_{\mathrm{i} 2018}+\beta_{2} \text { State_Test }_{\mathrm{i} 2018}+\beta_{3} \text { National_Test }_{\mathrm{i} 2018}+ \\
& \beta_{4} N o \_ \text {Copay }_{\mathrm{i} 2018}+\beta_{5} X_{\mathrm{i} 2018}+\varepsilon_{\mathrm{it}}
\end{aligned}
$$

Where the categorical dependent variable of interest Participation captures school leader $i$ 's expectation of participation in a hypothetical private school choice program in 2018 . The dependent variable is the private school leader's response on survey question 11, a Likert Scale ordered from one to five, with one indicating that the leader is "certain not to participate" and five indicating that the leader is "certain to participate." We use ordered probit regression (and ordered logit regression as a robustness check) because the dependent variable of interest is ordered and categorical. When interpreting marginal effects, we focus on the relative likelihood of private school leaders to choose the fifth outcome category (“certain to participate").

Because effective random assignment eliminates the need for controls, the base model only includes the three treatment indicators as independent variables. The first binary independent variable of interest, Open_Enroll, takes on the value of one if the private school was randomly assigned a random-admissions mandate, and zero otherwise. The second binary independent variable of interest, State_Test, takes on the value of one if the private school, $i$, was 
randomly assigned a state standardized testing mandate in the note of question 11 , and zero otherwise. The third binary independent variable of interest, National_Test, takes on the value of one if the private school was randomly assigned a nationally norm-referenced standardized testing mandate, and zero otherwise. The fourth binary independent variable of interest, No_Copay, takes on the value of one if the private school was randomly assigned a mandate stating that the school had to take the voucher funding as full-payment, and zero otherwise. We expect the coefficients on all four of these independent variables to be negative, indicating that these regulations reduce the likelihood of participation in private school choice programs.

Random assignment alone does not absolutely guarantee that all endogeneity will be removed from the models. Because of this possibility, we also include models with vector $X$ of observable control variables as robustness checks. These models control for the gender, race, and leadership positions of all respondents, school type, school level, state, tuition, and enrollment. Our main specification uses multiple-imputation for 2 missing tuition responses $(0.56$ percent of the overall analytic sample). Enders (2003) points out that missing data rates for education studies are regularly much higher than ours - between 15 and 20 percent. While there is not an exact cutoff for when the percentage of missing data becomes unacceptable, Schafer (1999) claims that missing rates below 5 percent are inconsequential, while Bennett (2001) contends that estimates are biased with missing rates exceeding 10 percent. Our multiple-imputation approach uses all other independent variables to impute missing tuition data (Rubin, 1987). We drop two observations ( 0.56 percent of the overall sample) that did not include a response to the participation question, since that is our dependent variable of interest. 


\section{Results}

Although all coefficients are in the expected direction, indicating that regulation reduces program participation, only the effects of half of the program regulations are statistically significant (Table 6). The strongest and most precise negative effects appear for the openenrollment regulation mandating that participating private schools admit all interested students on a random basis. Depending on the specification, our results indicate that, relative to no restrictions, open-enrollment regulation reduces the likelihood that private school leaders are “certain to participate" by around 19 to 23 percentage points, or 60 to 73 percent (31.5 percent of the control group responded that they were "certain to participate"). These negative effects on participation are large, amounting to 40 to 49 percent of a standard deviation ("certain participation" had a standard deviation of 46.8 percent for the control group).

Table 6: Effects of Regulations on Reported Participation

\begin{tabular}{|c|c|c|c|c|}
\hline & $\begin{array}{c}\text { Participation } \\
\text { (Ordered Probit) }\end{array}$ & $\begin{array}{c}\text { Participation } \\
\text { (Ordered Logit) }\end{array}$ & $\begin{array}{c}\text { Participation } \\
\text { (Ordered Probit) }\end{array}$ & $\begin{array}{c}\text { Participation } \\
\text { (Ordered Logit) }\end{array}$ \\
\hline Open-Enrollment & $\begin{array}{l}-0.226^{* * *} \\
(0.000)\end{array}$ & $\begin{array}{l}-0.229 * * * \\
(0.000)\end{array}$ & $\begin{array}{l}-0.197 * * * \\
(0.000)\end{array}$ & $\begin{array}{l}-0.189 \text { *** } \\
(0.001)\end{array}$ \\
\hline State Testing & $\begin{array}{l}-0.104 * \\
(0.039)\end{array}$ & $\begin{array}{l}-0.102 * \\
(0.040)\end{array}$ & $\begin{array}{l}-0.090+ \\
(0.057)\end{array}$ & $\begin{array}{l}-0.092+ \\
(0.059)\end{array}$ \\
\hline National Testing & $\begin{array}{l}-0.050 \\
(0.355)\end{array}$ & $\begin{array}{l}-0.044 \\
(0.409)\end{array}$ & $\begin{array}{l}-0.025 \\
(0.636)\end{array}$ & $\begin{array}{l}-0.023 \\
(0.658)\end{array}$ \\
\hline Copay Prohibition & $\begin{array}{l}-0.015 \\
(0.752)\end{array}$ & $\begin{array}{l}-0.021 \\
(0.644)\end{array}$ & $\begin{array}{l}-0.004 \\
(0.936)\end{array}$ & $\begin{array}{l}-0.013 \\
(0.772)\end{array}$ \\
\hline Controls & No & No & Yes & Yes \\
\hline Pseudo R-Squared & 0.0214 & 0.0220 & 0.0876 & 0.0908 \\
\hline $\mathrm{N}$ & 354 & 354 & 354 & 354 \\
\hline
\end{tabular}


Each model also detects negative effects for state standardized testing requirements. Depending on the model employed, we find that mandated state standardized testing using the official state accountability test reduces the likelihood private school leaders are "certain to participate" by 9 to over 10 percentage points, or about 29 to 33 percent. These effects are moderate in size, as they are equivalent to a 19 to 22 percent of a standard deviation reduction in certain program participation. While all of the coefficients measuring the effects of the nationally norm-referenced standardized testing mandate and the prohibition of copayment on participation are negative, none of them are statistically significant at even the marginal (p-value $<10$ percent) level. It is not surprising that the state standardized testing mandate significantly decreases participation while the relationship is not statistically significant for the nationally normreferenced testing requirement. The state standardized testing mandate is more restrictive to private schools because it does not allow private school leaders to choose the standardized tests that their students take. In addition, adjustment costs may be lower for the nationally normreferenced testing mandate than the state testing requirement if private schools are already administering norm-referenced tests before the participation decision.

The few statistically significant control variable relationships are also worth noting. As found by Sude, DeAngelis, and Wolf (2018) and DeAngelis, Burke, and Wolf (2018) in other research, higher tuition schools are less likely to participate in school choice programs, all else being equal. In our sample, a $\$ 1,000$ increase in tuition is associated with around a 0.55 percentage point, or about a 1.75 percent, reduction in certain program participation, suggesting that higher quality (or at least more expensive) schools are less likely to participate in choice programs. "American Indian or Alaska Native" school leaders are 40 percentage points more likely to be certain to participate than white leaders. "Native Hawaiian or Other Pacific Islander" 
school leaders are 19 percentage points less likely to be certain to participate than white leaders, all else being equal. Leaders of Montessori schools are 16 percentage points less likely to be certain to participate than are leaders of regular schools, all else being equal, perhaps because regulations are more costly to their specialized educational models. Importantly, this negative relationship reported for Montessori schools is detected in another study using 2015-16 data from actual voucher program participation decisions in Milwaukee, Wisconsin; Indiana; Ohio; Louisiana; D.C.; and North Carolina (DeAngelis, 2019). "Administrators" and "other leaders" were both about 11 percentage points less likely to be certain to participate than school principals, all else being equal. We do not detect any differences in participation proclivity by school level or state.

As shown in Table 7 below, the outcome response category examined does not change the overall results. All effects are statistically significant at the $\mathrm{p}<0.05$ level for openenrollment mandates (and at the $\mathrm{p}<0.10$ level for state testing requirements) across all five response categories. For example, the open-enrollment regulation increases the likelihood that private school leaders are "certain not to participate" by around 15 percentage points and state standardized testing requirements increase the likelihood that private school leaders are "certain not to participate" by around 7 percentage points. All categories are statistically insignificant for the prohibition of parental copayment and nationally norm-referenced testing requirements. 
Table 7: Effects of Regulations on Reported Participation by Category

\begin{tabular}{|c|c|c|c|c|c|}
\hline & $\begin{array}{l}\text { Certain Not } \\
\text { to Participate }\end{array}$ & $\begin{array}{l}\text { Very Little } \\
\text { Chance }\end{array}$ & Some Chance & $\begin{array}{l}\text { Very Good } \\
\text { Chance }\end{array}$ & $\begin{array}{l}\text { Certain to } \\
\text { Participate }\end{array}$ \\
\hline Open-Enrollment & $\begin{array}{l}0.148^{* * * *} \\
(0.000)\end{array}$ & $\begin{array}{l}0.065^{* * *} \\
(0.001)\end{array}$ & $\begin{array}{l}0.046 * * * \\
(0.001)\end{array}$ & $\begin{array}{l}-0.062 * * * \\
(0.001)\end{array}$ & $\begin{array}{l}-0.197 * * * \\
(0.000)\end{array}$ \\
\hline State Testing & $\begin{array}{l}0.068+ \\
(0.057)\end{array}$ & $\begin{array}{l}0.030+ \\
(0.068)\end{array}$ & $\begin{array}{l}0.021+ \\
(0.066)\end{array}$ & $\begin{array}{l}-0.028+ \\
(0.064)\end{array}$ & $\begin{array}{l}-0.090+ \\
(0.057)\end{array}$ \\
\hline National Testing & $\begin{array}{l}0.019 \\
(0.636)\end{array}$ & $\begin{array}{l}0.008 \\
(0.636)\end{array}$ & $\begin{array}{l}0.006 \\
(0.635)\end{array}$ & $\begin{array}{l}-0.008 \\
(0.636)\end{array}$ & $\begin{array}{l}-0.025 \\
(0.636)\end{array}$ \\
\hline Copay Prohibition & $\begin{array}{l}0.003 \\
(0.936)\end{array}$ & $\begin{array}{l}0.001 \\
(0.936)\end{array}$ & $\begin{array}{l}0.001 \\
(0.936)\end{array}$ & $\begin{array}{l}-0.001 \\
(0.936)\end{array}$ & $\begin{array}{l}-0.004 \\
(0.936)\end{array}$ \\
\hline Controls & Yes & Yes & Yes & Yes & Yes \\
\hline Pseudo R-Squared & 0.0876 & 0.0876 & 0.0876 & 0.0876 & 0.0876 \\
\hline $\mathrm{N}$ & 354 & 354 & 354 & 354 & 354 \\
\hline
\end{tabular}

\section{Heterogeneous Effects}

The general effects of the open enrollment and state testing mandates are to reduce the likelihood of a private school participating in a school choice program. Do those general effects vary by state, school specialization, or proxy measures of school quality? Here we explore that question.

\section{States}

The only statistically significant relationships detected are for the subsample from California, perhaps because less than one-third of the observations came from New York (Table 8). The negative effects detected in California are larger than the overall results. Specifically, we find that the open-enrollment regulation leads to a 23 to 27 percentage point, or 73 to 86 percent, reduction in the likelihood of "certain" participation in California and the state testing mandate leads to around a 15 percentage point, or 48 percent, reduction. The last two columns of Table 8 
indicate that the larger effects for state standardized testing in California are statistically different from the effects in New York at the $\mathrm{p}<0.10$ level. While the coefficient on open-enrollment ranges from negative 10 to negative 15 percentage points for New York, suggesting a lower likelihood of program participation, none of our models detect statistically significant effects for the Empire State, as the p-values range from 10.4 percent to 27.6 percent. In addition, we do not find evidence that the effects for open-enrollment mandates are statistically different across states. No effects are detected for the nationally norm-referenced testing mandate or the prohibition of copayment for either state; however, we find evidence to suggest that the effects of copay prohibition differ across states, as the positive coefficient on the copay prohibition in New York is significantly different from the negative coefficient on the same copay prohibition in California. Such a heterogeneous effect could be explained by differences in financial security and social responsibility in private schools across the two states. 
Table 8: Effects of Regulations on Reported Participation (by State)

\begin{tabular}{|c|c|c|c|c|}
\hline & $\begin{array}{c}\text { Participation } \\
\text { (Ordered Probit) }\end{array}$ & $\begin{array}{c}\text { Participation } \\
\text { (Ordered Logit) }\end{array}$ & $\begin{array}{c}\text { Participation } \\
\text { (Ordered Probit) }\end{array}$ & $\begin{array}{c}\text { Participation } \\
\text { (Ordered Logit) }\end{array}$ \\
\hline Open-Enrollment (CA) & $\begin{array}{l}-0.267 * * * \\
(0.000)\end{array}$ & $\begin{array}{l}-0.271 * * * \\
(0.000)\end{array}$ & $\begin{array}{l}-0.230 * * * \\
(0.001)\end{array}$ & $\begin{array}{l}-0.234 * * * \\
(0.001)\end{array}$ \\
\hline Open-Enrollment (NY) & $\begin{array}{l}-0.147 \\
(0.104)\end{array}$ & $\begin{array}{l}-0.148 \\
(0.111)\end{array}$ & $\begin{array}{l}-0.120 \\
(0.155)\end{array}$ & $\begin{array}{l}-0.097 \\
(0.276)\end{array}$ \\
\hline Difference & $\begin{array}{l}0.119 \\
(0.296)\end{array}$ & $\begin{array}{l}0.123 \\
(0.290)\end{array}$ & $\begin{array}{l}0.111 \\
(0.300)\end{array}$ & $\begin{array}{l}0.137 \\
(0.220) \\
\end{array}$ \\
\hline State Testing $(\mathrm{CA})$ & $\begin{array}{l}-0.155^{*} \\
(0.014)\end{array}$ & $\begin{array}{l}-0.150 * \\
(0.019)\end{array}$ & $\begin{array}{l}-0.147^{*} \\
(0.013)\end{array}$ & $\begin{array}{l}-0.153^{*} \\
(0.011)\end{array}$ \\
\hline State Testing (NY) & $\begin{array}{l}0.007 \\
(0.931)\end{array}$ & $\begin{array}{l}-0.006 \\
(0.934)\end{array}$ & $\begin{array}{l}0.035 \\
(0.645)\end{array}$ & $\begin{array}{l}0.036 \\
(0.654)\end{array}$ \\
\hline Difference & $\begin{array}{l}0.162 \\
(0.111)\end{array}$ & $\begin{array}{l}0.143 \\
(0.158)\end{array}$ & $\begin{array}{l}0.182+ \\
(0.061) \\
\end{array}$ & $\begin{array}{l}0.189+ \\
(0.059) \\
\end{array}$ \\
\hline National Testing (CA) & $\begin{array}{l}-0.055 \\
(0.387)\end{array}$ & $\begin{array}{l}-0.054 \\
(0.395)\end{array}$ & $\begin{array}{l}-0.030 \\
(0.621)\end{array}$ & $\begin{array}{l}-0.038 \\
(0.534)\end{array}$ \\
\hline National Testing (NY) & $\begin{array}{l}-0.035 \\
(0.753)\end{array}$ & $\begin{array}{l}-0.013 \\
(0.907)\end{array}$ & $\begin{array}{l}0.013 \\
(0.913)\end{array}$ & $\begin{array}{l}-0.018 \\
(0.850)\end{array}$ \\
\hline Difference & $\begin{array}{l}0.020 \\
(0.876)\end{array}$ & $\begin{array}{l}0.041 \\
(0.750)\end{array}$ & $\begin{array}{l}-0.013 \\
(0.913)\end{array}$ & $\begin{array}{l}0.019 \\
(0.864)\end{array}$ \\
\hline Copay Prohibition (CA) & $\begin{array}{l}-0.057 \\
(0.311)\end{array}$ & $\begin{array}{l}-0.065 \\
(0.240)\end{array}$ & $\begin{array}{l}-0.051 \\
(0.344)\end{array}$ & $\begin{array}{l}-0.067 \\
(0.212)\end{array}$ \\
\hline Copay Prohibition (NY) & $\begin{array}{l}0.106 \\
(0.217)\end{array}$ & $\begin{array}{l}0.103 \\
(0.194)\end{array}$ & $\begin{array}{l}0.122 \\
(0.136)\end{array}$ & $\begin{array}{l}0.126 \\
(0.123) \\
\end{array}$ \\
\hline Difference & $\begin{array}{l}-0.057 \\
(0.311) \\
\end{array}$ & $\begin{array}{l}0.168+ \\
(0.083) \\
\end{array}$ & $\begin{array}{l}0.173+ \\
(0.075) \\
\end{array}$ & $\begin{array}{l}0.193^{*} \\
(0.046) \\
\end{array}$ \\
\hline Controls & No & No & Yes & Yes \\
\hline Pseudo R-Squared & 0.0303 & 0.0302 & 0.0929 & 0.0963 \\
\hline $\mathrm{N}$ & 354 & 354 & 354 & 354 \\
\hline \multicolumn{5}{|c|}{$\begin{array}{l}\text { Notes: P-values in parentheses. }+\mathrm{p}<0.10,{ }^{*} \mathrm{p}<0.05, * * \mathrm{p}<0.01, * * * \mathrm{p}<0.001 \text {. Average marginal effects are reported } \\
\text { for the last outcome category of "certain to participate." Models in the first two columns include interactions } \\
\text { between each treatment and state and an indicator variable for state. Models in the last two columns use controls for } \\
\text { the gender, race, and position of respondents, school type, tuition, enrollment, and school level. The last two } \\
\text { columns use multiple-imputation for } 4 \text { missing tuition values. }\end{array}$} \\
\hline
\end{tabular}




\section{Specialization}

In theory, private schools with educational models already mirroring the practices of the traditional public schools face lower adjustment costs associated with program participation. In other words, specialized private schools should be less likely to participate in voucher programs than private schools that already mirror public school practices. Previous correlational work has found that more specialized private schools are less likely to participate in voucher programs (DeAngelis, 2019), and voucher program regulations might lead to less specialization over time (DeAngelis \& Burke, 2017).

Table 9 below presents the first experimental evidence regarding whether or not more specialized schools are more likely to be deterred by voucher program regulations. We find that the open-enrollment mandate reduces the likelihood that non-regular private school leaders report "certain" participation by around 24 to 27 percentage points, or 76 to 86 percent. This negative effect is only around 16 to 17 percentage points, or 51 to 54 percent, for regular private schools. However, while the coefficients differ in size, the differences are not statistically significant. In fact, no statistically significant heterogeneous effects are found for any of the four regulations based on private school specialization. 
Table 9: Effects of Regulations on Reported Participation (by School Specialization)

\begin{tabular}{|c|c|c|c|c|}
\hline & $\begin{array}{l}\text { Participation } \\
\text { (Ordered } \\
\text { Probit) } \\
\end{array}$ & $\begin{array}{l}\text { Participation } \\
\text { (Ordered } \\
\text { Logit) } \\
\end{array}$ & $\begin{array}{l}\text { Participation } \\
\text { (Ordered } \\
\text { Probit) } \\
\end{array}$ & $\begin{array}{l}\text { Participation } \\
\text { (Ordered } \\
\text { Logit) } \\
\end{array}$ \\
\hline Open-Enrollment (Non-Regular) & $\begin{array}{l}-0.266^{* *} \\
(0.005)\end{array}$ & $\begin{array}{l}-0.241 * \\
(0.012)\end{array}$ & $\begin{array}{l}-0.251 * * \\
(0.005)\end{array}$ & $\begin{array}{l}-0.240 * \\
(0.013)\end{array}$ \\
\hline Open-Enrollment (Regular) & $\begin{array}{l}-0.159 * \\
(0.025)\end{array}$ & $\begin{array}{l}-0.170 * \\
(0.020)\end{array}$ & $\begin{array}{l}-0.167 * \\
(0.012)\end{array}$ & $\begin{array}{l}-0.165^{*} \\
(0.017)\end{array}$ \\
\hline Difference & $\begin{array}{l}0.107 \\
(0.365) \\
\end{array}$ & $\begin{array}{l}0.070 \\
(0.558) \\
\end{array}$ & $\begin{array}{l}0.084 \\
(0.444) \\
\end{array}$ & $\begin{array}{l}0.075 \\
(0.518) \\
\end{array}$ \\
\hline State Testing (Non-Regular) & $\begin{array}{l}-0.103 \\
(0.264)\end{array}$ & $\begin{array}{l}-0.089 \\
(0.343)\end{array}$ & $\begin{array}{l}-0.087 \\
(0.315)\end{array}$ & $\begin{array}{l}-0.100 \\
(0.283)\end{array}$ \\
\hline State Testing (Regular) & $\begin{array}{l}-0.092 \\
(0.118) \\
\end{array}$ & $\begin{array}{c}-0.093+ \\
(0.098)\end{array}$ & $\begin{array}{l}-0.094+ \\
(0.091)\end{array}$ & $\begin{array}{l}-0.093 \\
(0.104)\end{array}$ \\
\hline Difference & $\begin{array}{l}0.011 \\
(0.919)\end{array}$ & $\begin{array}{l}-0.004 \\
(0.972) \\
\end{array}$ & $\begin{array}{l}-0.007 \\
(0.946)\end{array}$ & $\begin{array}{l}0.007 \\
(0.948)\end{array}$ \\
\hline National Testing (Non-Regular) & $\begin{array}{l}-0.114 \\
(0.266)\end{array}$ & $\begin{array}{l}-0.109 \\
(0.301)\end{array}$ & $\begin{array}{l}-0.087 \\
(0.397)\end{array}$ & $\begin{array}{l}-0.100 \\
(0.363)\end{array}$ \\
\hline National Testing (Regular) & $\begin{array}{l}-0.005 \\
(0.930)\end{array}$ & $\begin{array}{l}-0.005 \\
(0.932)\end{array}$ & $\begin{array}{l}0.001 \\
(0.985)\end{array}$ & $\begin{array}{l}0.005 \\
(0.924)\end{array}$ \\
\hline Difference & $\begin{array}{l}0.109 \\
(0.362)\end{array}$ & $\begin{array}{l}0.104 \\
(0.384)\end{array}$ & $\begin{array}{l}0.088 \\
(0.444)\end{array}$ & $\begin{array}{l}0.106 \\
(0.377) \\
\end{array}$ \\
\hline Copay Prohibition (Non-Regular) & $\begin{array}{l}-0.027 \\
(0.770)\end{array}$ & $\begin{array}{l}-0.017 \\
(0.854)\end{array}$ & $\begin{array}{l}-0.035 \\
(0.706)\end{array}$ & $\begin{array}{l}-0.046 \\
(0.626)\end{array}$ \\
\hline Copay Prohibition (Regular) & $\begin{array}{l}-0.018 \\
(0.743)\end{array}$ & $\begin{array}{l}-0.027 \\
(0.599)\end{array}$ & $\begin{array}{l}0.008 \\
(0.879)\end{array}$ & $\begin{array}{l}-0.003 \\
(0.953)\end{array}$ \\
\hline Difference & $\begin{array}{l}0.009 \\
(0.930) \\
\end{array}$ & $\begin{array}{l}-0.010 \\
(0.924) \\
\end{array}$ & $\begin{array}{l}0.043 \\
(0.685) \\
\end{array}$ & $\begin{array}{l}0.043 \\
(0.682) \\
\end{array}$ \\
\hline Controls & No & No & Yes & Yes \\
\hline Pseudo R-Squared & 0.0391 & 0.0400 & 0.0890 & 0.0921 \\
\hline $\mathrm{N}$ & 354 & 354 & 354 & 354 \\
\hline \multicolumn{5}{|c|}{$\begin{array}{l}\text { Notes: P-values in parentheses. }+\mathrm{p}<0.10, * \mathrm{p}<0.05, * * \mathrm{p}<0.01, * * * \mathrm{p}<0.001 \text {. Average marginal effects are reported } \\
\text { for the last outcome category of "certain to participate." All } 4 \text { independent variables of interest are interacted with } \\
\text { whether the private school is classified as "non-regular." Models in the first two columns control for whether the } \\
\text { private school is classified as "non-regular." Models in the last two columns also use controls for gender, race, and } \\
\text { position of respondents, school type, tuition, enrollment, state, and school level. All columns use multiple- } \\
\text { imputation for } 4 \text { missing tuition values. }\end{array}$} \\
\hline
\end{tabular}




\section{Quality}

Regulations could most deter higher-quality schools from participating in private school choice programs. Lower-quality private schools may be more likely to participate in voucher programs, regardless of the additional regulations, because they are more likely to be in great need of financial resources and enrollment. On the other hand, leaders of higher-quality private schools may be less likely to accept voucher regulations if they perceive that the additional regulations might alter the educational models that are already working for their students and in demand by their paying customers.

Four empirical evaluations have found that higher quality private schools, as measured by tuition, enrollment, and customer reviews, are less likely to participate in voucher programs in Chile and across the U.S. (Abdulkadiroğlu, Pathak, \& Walters, 2018; DeAngelis \& Hoarty, 2018; Sánchez, 2018; Sude, DeAngelis, \& Wolf, 2018). However, none of these studies are able to determine whether regulations or other factors deterred higher-quality private schools from participating in voucher programs. Our previous experimental evaluation was the first to examine that question rigorously. We found limited evidence to suggest that regulations were more likely to deter higher-quality private schools, as measured by tuition and enrollment trends, from participating in a hypothetical voucher program in Florida (DeAngelis, Burke, \& Wolf, 2018).

The tables below report more evidence regarding the question of whether or not regulations are more likely to deter higher quality private schools than lower quality ones from voucher program participation. Each of the models uses an interaction term for each of the four regulations and the quality metrics. We perform subgroup analyses using four proxies for private school quality: reported school tuition levels, enrollment trends from the 2013-14 school year to 
the 2015-16 school year as reported by the Private School Universe Survey, Google review scores, and GreatSchools review scores. Tuition levels represent the price families are willing to pay for the school's educational services, enrollment trends represent the explicit change in demand for the school's educational services over time, and customer reviews represent customer satisfaction levels. Abdulkadiroğlu, Pathak, and Walters (2018) found that tuition levels and enrollment trends in private schools in Louisiana were both positively associated with their experimental impacts on student achievement.

We find limited evidence to suggest that higher quality schools, as measured by customer review scores, are more likely to be deterred by voucher program regulations. All coefficients on open-enrollment mandates, state testing requirements, and copay prohibition are in the expected negative direction for Google review scores; however, only one analytic model detects marginally significant effects for one regulation (Table 10). Specifically, our ordered logit model without additional controls suggests that a one-unit increase (on a five-unit scale) in Google review score is associated with a 14.5 percentage point larger negative effect of the state testing mandate on certain program participation; however, the three other analytic models do not produce statistically significant interaction results, as they have p-values between 11.4 percent and 14.1 percent. While no overall quality-reducing effects are detected based on GreatSchools review scores, all coefficients are in the expected negative direction (Table 11). Our measures of average Google and GreatSchools review scores are continuous and range from 1 to 5. We find no evidence overall to suggest that schools with higher tuition (Table 12) or higher enrollment trends (Table 13) are more likely to be deterred by any of the four regulations. This result is surprising as our previous experimental evaluation in Florida detected statistically significant effects for both of these interaction terms (DeAngelis, Burke, \& Wolf, 2018). 
Table 10: Effects of Regulations on Reported Participation (by Google Review Score)

\begin{tabular}{|c|c|c|c|c|}
\hline & $\begin{array}{c}\text { Participation } \\
\text { (Ordered Probit) }\end{array}$ & $\begin{array}{c}\text { Participation } \\
\text { (Ordered Logit) }\end{array}$ & $\begin{array}{c}\text { Participation } \\
\text { (Ordered Probit) }\end{array}$ & $\begin{array}{c}\text { Participation } \\
\text { (Ordered Logit) }\end{array}$ \\
\hline Open-Enrollment & $\begin{array}{l}-0.074 \\
(0.352)\end{array}$ & $\begin{array}{l}-0.079 \\
(0.310)\end{array}$ & $\begin{array}{l}-0.103 \\
(0.159)\end{array}$ & $\begin{array}{l}-0.112 \\
(0.128)\end{array}$ \\
\hline State Testing & $\begin{array}{l}-0.128 \\
(0.141)\end{array}$ & $\begin{array}{l}-0.145+ \\
(0.098)\end{array}$ & $\begin{array}{l}-0.118 \\
(0.136)\end{array}$ & $\begin{array}{l}-0.130 \\
(0.114)\end{array}$ \\
\hline National Testing & $\begin{array}{l}-0.021 \\
(0.798)\end{array}$ & $\begin{array}{l}-0.030 \\
(0.710)\end{array}$ & $\begin{array}{l}0.031 \\
(0.680)\end{array}$ & $\begin{array}{l}0.019 \\
(0.799)\end{array}$ \\
\hline Copay Prohibition & $\begin{array}{l}-0.033 \\
(0.717)\end{array}$ & $\begin{array}{l}-0.055 \\
(0.580)\end{array}$ & $\begin{array}{l}-0.016 \\
(0.832)\end{array}$ & $\begin{array}{l}-0.040 \\
(0.617)\end{array}$ \\
\hline Controls & No & No & Yes & Yes \\
\hline Pseudo R-Squared & 0.0267 & 0.0280 & 0.1043 & 0.1081 \\
\hline $\mathrm{N}$ & 313 & 313 & 313 & 313 \\
\hline \multicolumn{5}{|c|}{$\begin{array}{l}\text { Notes: P-values in parentheses. }+\mathrm{p}<0.10,{ }^{*} \mathrm{p}<0.05, * * \mathrm{p}<0.01, * * * \mathrm{p}<0.001 \text {. Average marginal effects are reported } \\
\text { for the last outcome category of "certain to participate." All } 4 \text { independent variables of interest are interacted with } \\
\text { average Google customer review score (a continuous measure on a 5-point scale). The table reports the coefficient } \\
\text { on the continuous interaction term for each treatment and model. Models in the first two columns control for Google } \\
\text { review score. Models in the last two columns also use controls for gender, race, and position of respondents, school } \\
\text { type, tuition, enrollment, state, and school level. All columns use multiple-imputation for } 4 \text { missing tuition values. } \\
\text { All columns show the coefficients of the interaction terms. All models drop } 41 \text { observations (11.58 percent of the } \\
\text { sample) missing Google review scores. }\end{array}$} \\
\hline
\end{tabular}


Table 11: Effects of Regulations on Reported Participation by GreatSchools Review Score

\begin{tabular}{lllll}
\hline & $\begin{array}{c}\text { Participation } \\
\text { (Ordered Probit) }\end{array}$ & $\begin{array}{c}\text { Participation } \\
\text { (Ordered Logit) }\end{array}$ & $\begin{array}{c}\text { Participation } \\
\text { (Ordered Probit) }\end{array}$ & $\begin{array}{c}\text { Participation } \\
\text { (Ordered Logit) }\end{array}$ \\
\hline Open-Enrollment & -0.067 & -0.059 & -0.074 & -0.064 \\
& $(0.384)$ & $(0.488)$ & $(0.316)$ & $(0.451)$ \\
State Testing & -0.080 & -0.067 & -0.039 & -0.032 \\
& $(0.267)$ & $(0.393)$ & $(0.598)$ & $(0.699)$ \\
National Testing & -0.115 & -0.102 & -0.106 & -0.084 \\
& $(0.224)$ & $(0.313)$ & $(0.226)$ & $(0.378)$ \\
Copay Prohibition & -0.096 & -0.085 & -0.099 & -0.100 \\
& $(0.159)$ & $(0.246)$ & $(0.113)$ & $(0.152)$ \\
Controls & No & No & Yes & Yes \\
\hline Pseudo R-Squared & 0.0236 & & & 0.0958 \\
\hline N & 309 & 0.0236 & 0.0952 & 309 \\
\hline
\end{tabular}

Notes: P-values in parentheses. $+\mathrm{p}<0.10,{ }^{*} \mathrm{p}<0.05,{ }^{*} \mathrm{p}<0.01,{ }^{* * *} \mathrm{p}<0.001$. Average marginal effects are reported for the last outcome category of "certain to participate." All 4 independent variables of interest are interacted with average GreatSchools customer review score (a continuous measure on a 5-point scale). Models in the first two columns control for GreatSchools review score. The table reports the coefficient on the continuous interaction term for each treatment and model. Models in the last two columns also use controls for gender, race, and position of respondents, school type, tuition, enrollment, state, and school level. All columns use multiple-imputation for 4 missing tuition values. All models drop 45 observations (12.71 percent of the sample) missing GreatSchools review scores. 
Table 12: Effects of Regulations on Reported Participation by Tuition

\begin{tabular}{lllll}
\hline & $\begin{array}{c}\text { Participation } \\
\text { (Ordered Probit) }\end{array}$ & $\begin{array}{c}\text { Participation } \\
\text { (Ordered Logit) }\end{array}$ & $\begin{array}{c}\text { Participation } \\
\text { (Ordered Probit) }\end{array}$ & $\begin{array}{c}\text { Participation } \\
\text { (Ordered Logit) }\end{array}$ \\
\hline Open-Enrollment & -0.003 & -0.002 & -0.001 & -0.002 \\
& $(0.406)$ & $(0.549)$ & $(0.672)$ & $(0.603)$ \\
State Testing & -0.002 & -0.001 & -0.001 & -0.001 \\
National Testing & $(0.604)$ & $(0.707)$ & $(0.820)$ & $(0.886)$ \\
& 0.001 & -0.000 & 0.003 & 0.002 \\
Copay Prohibition & $(0.806)$ & $(0.915)$ & $(0.436)$ & $(0.656)$ \\
& 0.002 & 0.002 & 0.001 & 0.001 \\
Controls & $(0.619)$ & $(0.549)$ & $(0.765)$ & $(0.779)$ \\
& No & No & Yes & Yes \\
\hline Pseudo R-Squared & 0.0414 & 0.0425 & 0.0893 & 0.0917 \\
\hline $\mathrm{N}$ & 354 & 354 & 354 & 354 \\
\hline
\end{tabular}

Notes: P-values in parentheses. $+\mathrm{p}<0.10,{ }^{*} \mathrm{p}<0.05$, $* * \mathrm{p}<0.01,{ }^{* * *} \mathrm{p}<0.001$. Average marginal effects are reported for the last outcome category of "certain to participate." All 4 independent variables of interest are interacted with reported private school tuition (a continuous measure reported in thousands of U.S. dollars). The table reports the coefficient on the continuous interaction term for each treatment and model. Models in the first two columns control for tuition. Models in the last two columns also use controls for gender, race, and position of respondents, school type, tuition, enrollment, state, and school level. All columns use multiple-imputation for 4 missing tuition values. 
Table 13: Effects of Regulations on Reported Participation by Enrollment Change

\begin{tabular}{|c|c|c|c|c|}
\hline & $\begin{array}{c}\text { Participation } \\
\text { (Ordered Probit) }\end{array}$ & $\begin{array}{c}\text { Participation } \\
\text { (Ordered Logit) }\end{array}$ & $\begin{array}{c}\text { Participation } \\
\text { (Ordered Probit) }\end{array}$ & $\begin{array}{c}\text { Participation } \\
\text { (Ordered Logit) }\end{array}$ \\
\hline Open-Enrollment & $\begin{array}{l}-0.001 \\
(0.739)\end{array}$ & $\begin{array}{l}-0.001 \\
(0.626)\end{array}$ & $\begin{array}{l}-0.000 \\
(0.698)\end{array}$ & $\begin{array}{l}-0.001 \\
(0.646)\end{array}$ \\
\hline State Testing & $\begin{array}{l}0.000 \\
(0.811)\end{array}$ & $\begin{array}{l}0.000 \\
(0.838)\end{array}$ & $\begin{array}{l}-0.001 \\
(0.445)\end{array}$ & $\begin{array}{l}-0.001 \\
(0.419)\end{array}$ \\
\hline National Testing & $\begin{array}{l}0.001 \\
(0.424)\end{array}$ & $\begin{array}{l}0.001 \\
(0.503)\end{array}$ & $\begin{array}{l}0.000 \\
(0.698)\end{array}$ & $\begin{array}{l}0.000 \\
(0.858)\end{array}$ \\
\hline Copay Prohibition & $\begin{array}{l}0.001 \\
(0.334)\end{array}$ & $\begin{array}{l}0.001 \\
(0.388)\end{array}$ & $\begin{array}{l}0.001 \\
(0.480)\end{array}$ & $\begin{array}{l}0.001 \\
(0.614)\end{array}$ \\
\hline Controls & No & No & Yes & Yes \\
\hline Pseudo R-Squared & 0.0229 & 0.0237 & 0.1144 & 0.1216 \\
\hline $\mathrm{N}$ & 237 & 237 & 237 & 237 \\
\hline \multicolumn{5}{|c|}{$\begin{array}{l}\text { Notes: P-values in parentheses. }+\mathrm{p}<0.10, * \mathrm{p}<0.05, * * \mathrm{p}<0.01, * * * \mathrm{p}<0.001 \text {. Average marginal effects are reported } \\
\text { for the last outcome category of "certain to participate." All } 4 \text { independent variables of interest are interacted with } \\
\text { private school enrollment change from the } 2013-14 \text { school year to the } 2015-16 \text { school year (in percentage points). } \\
\text { The table reports the coefficient on the continuous interaction term for each treatment and model. Models in the first } \\
\text { two columns control for enrollment change. Models in the last two columns also use controls for gender, race, and } \\
\text { position of respondents, school type, tuition, state, and school level. All columns use multiple-imputation for } 4 \\
\text { missing tuition values. All models drop } 117 \text { observations (33.05 percent of the sample) missing data for enrollment } \\
\text { change. }\end{array}$} \\
\hline
\end{tabular}

\section{Conclusions and Discussion}

As with the prior study in Florida, this study has important limitations. Even though the data collection instrument was administered in the field, the study was designed as a lab experiment (Blom-Hansen, Morton, \& Serritzlew, 2015). Participants were presented with a hypothetical situation and asked to describe their likely behavioral response. To the extent that the hypothetical situation, which in this case is a private school voucher program with an average voucher amount and a randomly assigned regulatory framework, did not seem real to the participants, their responses may not reflect how they would behave when making an actual private school choice participation decision. Only 8.24 percent of private school principals across the two states responded to the survey. Respondents were similar to non-respondents on 
descriptive characteristics of their schools. If any survey non-response bias exists in our analysis, it is likely biasing our results towards zero for the one category of respondents (assigned the open-enrollment requirement) in which we observe the largest and most consistently significant negative effects. Finally, our study examined the effect of a single government regulation on the anticipation of private school leaders to participate or not in a private school choice program. Just about every voucher program in the U.S. comes with packages of regulations, which may have different effects on expected participation than specific regulations. Experimental research linking packages of regulations to expected and actual participation decisions would be especially helpful for policymakers.

The findings presented in this study suggest that certain regulations levied on a private school choice program reduce the likelihood of private school participation. As was the case in Florida, we find that regulations that would restrict the autonomy of private school leaders, specifically open-enrollment mandates and state standardized testing requirements, significantly reduce the likelihood that private school leaders expect to be "certain to participate" in a new private school voucher program. As noted above, the open-enrollment regulation decreases the likelihood that private school leaders are "certain to participate" by around 19 percentage points and state standardized testing requirements decrease the likelihood that private school leaders are “certain to participate" by around 9 percentage points. All general findings are statistically insignificant for the prohibition of parental copayment and nationally norm-referenced testing requirements. Much more research is needed on the intersection between school choice regulations and private school participation decisions. In particular, more research on the effects of school choice regulations on the average quality and specialization of participating schools is needed to better inform policymakers. 


\section{References}

Abdulkadiroğlu, A., Pathak, P. A., \& Walters, C. R. (2018). Free to choose: can school choice reduce student achievement? American Economic Journal: Applied Economics, 10(1), $175-206$.

Bennett, D. A. (2001). How can I deal with missing data in my study? Australian and New Zealand Journal of Public Health, 25(5), 464-469.

Blom-Hansen, J., Morton, R., Serritzlew, S. (2015). Introduction: Experiments in public administration research. International Public Management Journal, 18(2), 151-170.

Brinig, M. F., \& Garnett, N. S. (2014). Lost classroom, lost community: Catholic schools' importance in urban America. Chicago, IL: University of Chicago Press.

Chubb, J. E., \& Moe, T. M. (1990). Politics, markets, and America's schools. Washington, D.C.: Brookings Institution Press.

DeAngelis, C. A. (2019). Which schools participate? An analysis of private school voucher program participation decisions across seven locations. SSRN Working Paper No. 3309754. Retrieved from https://ssrn.com/abstract=3309754.

DeAngelis, C. A., \& Burke, L. (2017). Does regulation induce homogenisation? An analysis of three voucher programmes in the United States. Educational Research and Evaluation, 23(7-8), 311-327. DOI: 10.1080/13803611.2018.1475242.

DeAngelis, C. A., Burke, L, \& Wolf, P. J. (2018). The Effects of Regulations on Private School Choice Program Participation: Experimental Evidence from Florida. EDRE Working Paper No. 2018-08. Retrieved from https://ssrn.com/abstract=3273428.

DeAngelis, C. A., \& Hoarty, B. (2018). Who participates? An analysis of school participation decisions in two voucher programs in the United States. Cato Institute Policy Analysis 
No. 848. Retrieved from https://www.cato.org/publications/policy-analysis/whoparticipates-analysis-school-participation-decisions-two-voucher EdChoice (2018). School choice in America dashboard. Retrieved from https://www.edchoice.org/school-choice/school-choice-in-america/\#

Enders, C. K. (2003). Using the expectation maximization algorithm to estimate coefficient alpha for scales with item-level missing data. Psychological Methods, 8(3), 322.

Hess, F. M. (2010). Does school choice “work”. National Affairs, 5(1), 35-53.

Kisida, B., Wolf, P. J., \& Rhinesmith, E. (2015). Views from private schools: Attitudes about school choice programs in three states. Washington, DC: American Enterprise Institute. Retrieved from https://eric.ed.gov/?id=ED555549.

McShane, M. Q. (Ed.). (2015). New and better schools: The supply side of school choice. Lanham, MD: Rowman \& Littlefield

McShane, M. Q. (2018). Rethinking regulation. Overseeing performance in a diversifying educational ecosystem. EdChoice. Retrieved from https://www.edchoice.org/wpcontent/uploads/2018/05/Rethinking-Regulation-by-Mike-McShane.pdf

Mills, J. N. (2015). The effectiveness of cash transfers as a policy instrument in K-16 education (Doctoral dissertation). University of Arkansas, Fayetteville. Retrieved from https://scholarworks.uark.edu/cgi/viewcontent.cgi?article=2204\&context=etd.

Mills, J. N., \& Wolf, P. J. (2017). Vouchers in the bayou: The effects of the Louisiana Scholarship Program on student achievement after 2 years. Educational Evaluation and Policy Analysis, 39(3), 464-484.

Murnane, R. J., Reardon, S. F., Mbekeani, P. P., \& Lamb, A. (2018). Who goes to private school: Long-term enrollment trends by family income. Education Next, 18(4), 58-67. 
Phillips, D. L., \& Clancy, K. J. (1972). Some effects of "social desirability" in survey studies. American Journal of Sociology, 77(5), 921-940.

Rubin, D. B. (1987). Multiple imputation for nonresponse in surveys. New York, NY: John Wiley \& Sons, Inc.

Sánchez, C. (2018). Understanding school competition under voucher regimes. University of Maryland. Retrieved from http://econweb.umd.edu/ sanchez/files/csanchez_jmp.pdf.

Schafer, J. L. (1999). Multiple imputation: a primer. Statistical Methods in Medical Research, $8(1), 3-15$.

Stuit, D., \& Doan, S. (2013). School choice regulations: Red tape or red herring. Washington, DC: Thomas B. Fordham Institute. Retrieved from https://edexcellence.net/publications/red-tape-or-red-herring.html.

Sude, Y., DeAngelis, C. A., \& Wolf, P. J. (2018). Supplying choice: An analysis of school participation decisions in voucher programs in Washington, DC, Indiana, and Louisiana. Journal of School Choice, 12(1), 8-33.

Wolf, P. J. (2012). The comprehensive longitudinal evaluation of the Milwaukee parental choice program: Summary of final reports (Milwaukee Evaluation Report \#36). School Choice Demonstration Project, University of Arkansas, Fayetteville, AR. Retrieved from http://www.uaedreform.org/downloads/2012/02/report-36-the-comprehensivelongitudinal-evaluation-of-the-milwaukee-parental-choice-program.pdf 


\section{Appendix: Survey Instrument}

\section{Control Group}

Q1: I agree to participate in this study and have read the consent form.

True

False

Q2: What is your first name?

Q3: What is your last name?

Q4: What is the name of your school?

Q5: What is your position at the school?

Principal

Director

Administrator

Other Leader

Q6: Please describe your race/ethnicity

White or Caucasian

Black or African American

Hispanic or Latino

Asian or Asian American

American Indian or Alaska Native

Native Hawaiian or other Pacific Islander

Another racelethnicity 
Q7: What is your gender?

Male

Female

Other

Q8: Which of the following best describes this school or program?

Regular school

Montessori school

Special program emphasis school (such as science or math school, performing arts

schools, talented or gifted school, etc.)

Special education school (primarily serves students with disabilities)

Career/Technical/Vocational school (primarily serves students being trained for occupations)

Early childhood program or day care center (such as kindergarten only, prekindergarten and kindergarten only, day care and transitional kindergarten only, etc.)

Alternative / other school (offers a curriculum designed to provide alternative or nontraditional education; does not specifically fall into the other categories listed)

Q9: What is your school's total enrollment?

Q10: What is the highest level of tuition charged at your school (In U.S. dollars)? 
Q11: If your state launched a new school choice program next academic year, with a value of $\$ 6,000$ per student, per year, how likely is it that your school would participate in the program? Note: This program would not require any changes in school operations or additional government regulations

Certain not to participate

Very little chance

Some chance

Very good chance

Certain to participate

\section{Treatment Group One}

Exactly the same as Control Group, but the note on Q11 says "The only requirement would be that every student would have to take the state standardized tests each year."

\section{Treatment Group Two}

Exactly the same as Control Group, but the note on Q11 says "The only requirement would be that your school would have to accept all students who applied (and you would be required to use random lottery for admissions in the case of oversubscription)."

\section{Treatment Group Three}

Exactly the same as Control Group, but the note on Q11 says "The only requirement would be that your school would have to accept the voucher amount $(\$ 6,000)$ as full payment for voucher students."

\section{Treatment Group Four}

Exactly the same as Control Group, but the note on Q11 says "The only requirement would be that every student would have to take nationally norm-referenced standardized tests each year." 